\title{
Identification and Analysis of Mitogen-Activated Protein Kinase (MAPK) Cascades in Fragaria vesca
}

\author{
Heying Zhou ${ }^{\dagger}$, Suyue Ren ${ }^{\dagger}$, Yuanfang Han, Qing Zhang, Ling Qin and Yu Xing * \\ Beijing Key Laboratory for Agricultural Application and New Technique, College of Plant Science and Technology, \\ Beijing Collaborative Innovation Center for Eco-Environmental Improvement with Forestry and Fruit Trees, \\ Beijing University of Agriculture, Beijing 102206, China; zhydyx2012@126.com (H.Z.); fenhui315@126.com (S.R.); \\ hanyuanfang186@163.com (Y.H.); zhangqing@bua.edu.cn (Q.Z.); qinling@bua.edu.cn (L.Q.) \\ * Correspondence: xingyu@bua.edu.cn; Tel.: +86-10-8079-7229 \\ t These authors contributed equally to this work.
}

Received: 24 July 2017; Accepted: 10 August 2017; Published: 13 August 2017

\begin{abstract}
Mitogen-activated protein kinase (MAPK) cascades are highly conserved signaling modules in eukaryotes, including yeasts, plants and animals. MAPK cascades are responsible for protein phosphorylation during signal transduction events, and typically consist of three protein kinases: MAPK, MAPK kinase, and MAPK kinase kinase. In this current study, we identified a total of 12 FvMAPK, 7 FvMAPKK, 73 FvMAPKKK, and one FvMAPKKKK genes in the recently published Fragaria vesca genome sequence. This work reported the classification, annotation and phylogenetic evaluation of these genes and an assessment of conserved motifs and the expression profiling of members of the gene family were also analyzed here. The expression profiles of the MAPK and $M A P K K$ genes in different organs and fruit developmental stages were further investigated using quantitative real-time reverse transcription PCR (qRT-PCR). Finally, the MAPK and MAPKK expression patterns in response to hormone and abiotic stresses (salt, drought, and high and low temperature) were investigated in fruit and leaves of $F$. vesca. The results provide a platform for further characterization of the physiological and biochemical functions of MAPK cascades in strawberry.
\end{abstract}

Keywords: Fragaria vesca; MAP kinase cascades; phylogenetic relationships; abiotic stresses; gene expression

\section{Introduction}

Plants are influenced by different biotic or abiotic stresses, thus in response have developed a few signaling networks to protect them at the molecular or cellular levels [1]. A series of inter-lined regulatory signaling networks is composed of some stress-activated molecular pathways [2]. The protein-kinase-based cascades associated with responses to extracellular stimuli are the mitogen-activated protein kinase (MAPK) cascades, which are conserved components of signal transduction pathways in eukaryotes ranging from yeast to plants and animals [3-6].

MAPK cascades involve protein phosphorylation events that contribute to signaling [3], and acknowledged eukaryotic MAPKs can be separated into three main subfamilies according to their structural characteristics, which is often related to their functions in various signal transduction pathways. The MAPK cascades classically are composed three protein kinases, MAPK (MAPK/MPK), MAPK kinase (MAPKK/MKK), and MAPK kinase kinase (MAPKKK/MAP3K), but sometimes contain a MAP3K kinase that phosphorylates the corresponding downstream substrates $[7,8]$. MAPK can catalyze the phosphorylation of a substrate protein by chemically adding phosphate groups from adenosine triphosphate (ATP) [9]. MAP3Ks are substantially serine or threonine kinases that phosphorylate MAP2Ks at a conserved S/T-X3-5-S/T motif [10-12]. MAPKs have TDY and TEY phosphorylation motifs in their activation loops, which can be phosphorylated by MAPKKs [1,9]. 
Plant MAPKs can be separated into four groups (A, B, C and D), in which members of Groups A, B and $C$ possess the TEY motif at its phosphorylation site, and members of Group D possesses the TDY motif [1].

In plants, MAPKs have been shown to phosphorylate different substrates, such as cytoskeleton binging proteins, transcription factors, and other kinases $[3,13]$. Many genes that encode MAPK cascades have been characterized from Arabidopsis thaliana, tobacco (Nicotiana tabacum), barley (Hordeum vulgare), maize (Zea mays), and rice (Oryza sativa) $[10,12,14,15]$. In A. thaliana, a complete MAPK cascade (MEKK1-MKK4/5-MAPK3/6) triggered by bacterial flagellin-derived peptide flg22 was characterized, which up-regulated the expression of the transcription factors of WRKY22/29 and then increased resistance to both fungal and bacterial pathogens [16]. CTR1 (the RAF-like MAP3K) plays an important role in leaf senescence and camalexin biosynthesis [17,18]. Many reports showed that MAPK cascades involved in different stress responses, such as drought, salt, cold or ABA treatment in different crops [19-29]. MKKs containing 11 catalytic subdomains are identified by a kinase domain and a K/R-K/R-K/R-X1-6-L-X-L/V/S MAPK-docking domain, and are functioned by phosphorylated their conserved serine and threonine residues (S/T-X3-5-S/T motif) [5]. MKKs can be classified into four groups according to the description in $A$. thaliana and rice, and several MKKs have been characterized in a variety of plant species [30]. Those MKKs are involved in several abiotic stresses. In A. thaliana, MKK1 mediated ABA induced CAT1 expression during drought stress; the FSD2/3 expressions were activated by MEKK1 via MKK5-MPK6-coupled signaling in salt stress; and MKK5 involved into high light induced CSD expressions [20-23]. SIPK and WIPK activated by NtMEK2 influenced cell death [31], and SIMKK played a key role in both salt- and elicitor-induced signals in alfalfa (Medicago sativa) [32,33].

As the largest class of MAPK cascades, the MAP3Ks can be divided into three subfamilies (MEKK, Raf and ZIK). A conserved G(T/S)Px(W/Y/F)MAPEV kinase domain can be found in the members of the MEKK subfamily, and in the ZIK subfamily, most of the proteins have the GTPEFMAPE(L/V)Y domain, while Raf subfamily members have the GTxx(W/Y)MAPE domain [8]. The members of the RAF subfamily have a kinase domain in C-terminal and a long regulatory domain in their N-terminal, compared with the members in the ZIK subfamily, which have the kinase domain in the N-terminal [34]. In A. thaliana, MEKK1 has been shown to regulate defense responses against bacteria and fungi [35], and a Raf-like MAP3K, AtEDR1, is involved in SA-inducible defense responses [36]. The ZIK subfamily, which contains 10 and 9 members in $A$. thaliana and rice, respectively, regulates flowering time and circadian rhythms [37].

The identification and characterization of different members of the MAPK cascades have been reported by functional genomic studies in various plant species, including $A$. thaliana, maize, rice, alfalfa, tobacco and grapevine (Vitis vinifera). They comprise complex gene families, which have been best studied in model plants, such as $A$. thaliana and rice [1,3,5,38-41]. There are at least 80 MAPKKKs, 10 MAPKKs and 20 MAPKs in the A. thaliana genome, whereas the rice genome contains at least 75 MAPKKKs, 8 MAPKKs and 17 MAPKs. Few MAPK cascades have been identified in fruit crops, although 14 MAPKs, 5 MAPKKs, 62 MAPKKKs and 7 MAPKKKKs were identified in the grapevine genome, and less is known in their regulatory mechanism and function. This is especially true for many fruit crops of horticultural value.

It is unknown in their functions of most MAPK in plants, but MAPK cascades have been identified in horticultural crops, such as grapevine and cucumber (Cucumis sativus) [34,42]. In the current study, we identified a total of 12 FvMAPKs, 7 FvMAPKKs, 73 FvMAPKKKs and 1 FvMAPKKKK from the recently published strawberry (F. vesca "Hawaii 4") genome [43]. We report the classification, annotation and a phylogenetic evaluation of these genes, and an assessment of conserved motifs and the results of expression profiling of members of the gene family were also analyzed here. The expression patterns of $M A P K$ cascades genes in different organs and different fruit developmental stages were further analyzed using quantitative real-time reverse transcription PCR (qRT-PCR), and the gene 
expression patterns in response to hormone and abiotic stress in leaves and fruit were also assessed. The results may provide information for further functional studies of this kind of kinases in strawberry.

\section{Results}

\subsection{Genome-Wide Identification of MAPK Cascade Genes in F. vesca}

A total of 12 MAPK, 7 MAPKK, 73 MAPKKK and 1 MAP4K open reading frames (ORFs) encoding putative MAPK cascade proteins were identified in the F. vesca genomic [43]. The number of FvMAPK genes (12) was less than in A. thaliana (20) and rice (17). Among them, the lengths of the deduced proteins ranged from 365 amino acids (FvMPK9) to 691 residues (FvMPK3), and the pI values ranged from 5.05 (FvMPK9) to 9.26 (FvMPK2). The number of genes in the MAPKK subfamily (7) was even lower than in A. thaliana, which has 10 members. In this subfamily, the full lengths of the protein sequences ranged from 244 to 518 amino acids; however, the pI values were similar to the FvMAPK proteins and ranged from 5.34 (FvMAPKK5) to 9.28 (FvMAPKK2). Among the 73 MAPKKKs, the pI values ranged from 4.50 to 10.09 (Table 1).

To investigate the genetic divergence within the MAPK cascade genes as well as the gene duplication patterns, the physical locations of the genes on the strawberry chromosomes were investigated (Figure 1). Ninety-three genes were mapped on all seven chromosomes, with distributions from ranging from 11 to 17 . Chromosomes 3 and 5 contained 17 MAPK cascade genes, and chromosomes $6,1,7,2$ and 4 contained 16, 13, 12, 11 and 7 genes, respectively.

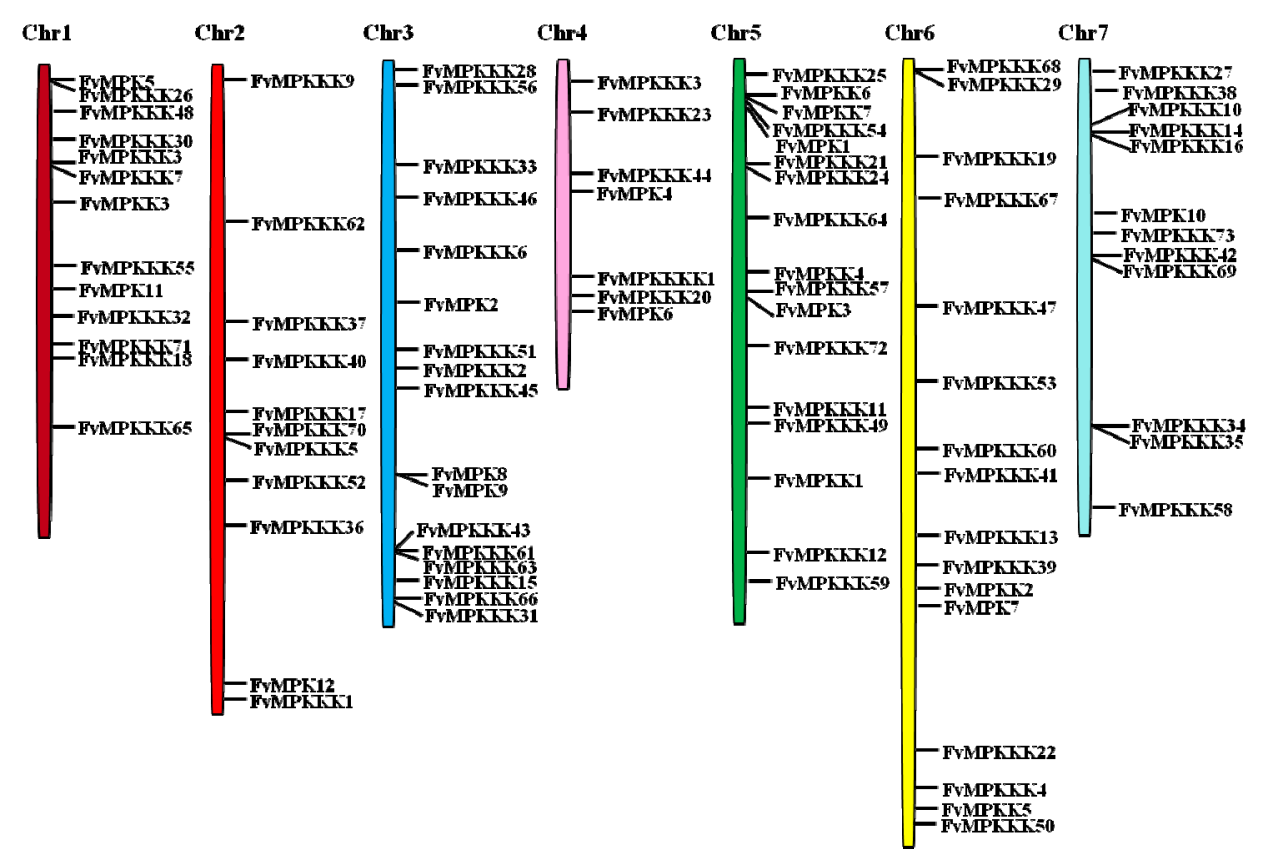

Figure 1. Chromosomal locations of strawberry MAPK, MAPKK, MAPKKK and MAP4K genes. Chr1-Chr7 represent the seven chromosomes. Black lines on bars indicate the locations of each gene.

A phylogenetic tree was generated to provide insights into the evolutionary divergence of the MAPK cascade from a common ancestor, and to infer evolutionary relationships among various genes or species. All predicted MAPK cascade protein sequences and the corresponding A. thaliana sequences were aligned, and a rooted phylogenetic tree was constructed by aligning full length amino acid sequences (Figures 2 and 3). The FvMAPK sequences were further divided into four subfamilies based on the conserved threonine and tyrosine residues in the TEY and TDY motifs in their phosphorylation activation loop (Figure 3A). Only one MAP4K was identified, and this was predicted to contain the conserved TFVGTPxWMAPEV motif. 
Table 1. MAPK cascade proteins identified in the Fragaria vesca genome.

\begin{tabular}{|c|c|c|c|c|c|c|c|c|c|c|}
\hline Gene Name & Gene ID & Chr & Location & ORF (aa) & mW (kDa) & pI & Instability Index & $\mathbf{A i}$ & GRAVY & Number of Exons \\
\hline \multicolumn{11}{|l|}{ MAPKs } \\
\hline MAPK1 & 101290762 & 5 & 1784699..1788845 & 377 & 43.24 & 6.4 & 46.14 & 90.53 & -0.37 & 6 \\
\hline MAPK2 & 101294541 & 3 & 11156420..11160717 & 609 & 69.37 & 9.26 & 32.32 & 83.92 & -0.44 & 10 \\
\hline$M A P K 3$ & 101295052 & 5 & 10188960..10193438 & 691 & 78.45 & 7.86 & 44.65 & 75.96 & -0.64 & 11 \\
\hline MAPK4 & 101295411 & 4 & 13067191..13073043 & 561 & 63.82 & 8.73 & 36.24 & 77.4 & -0.48 & 10 \\
\hline MAPK5 & 101297368 & 1 & 1081422..1084925 & 391 & 44.71 & 5.65 & 39.58 & 89.82 & -0.28 & 5 \\
\hline MAPK6 & 101300335 & 4 & $18603202 . .18607991$ & 580 & 66.33 & 7.07 & 38.18 & 80.53 & -0.55 & 12 \\
\hline$M A P K 7$ & 101306152 & 6 & $26819611 . .26825467$ & 618 & 70.68 & 9.23 & 37.11 & 81.12 & -0.47 & 10 \\
\hline MAPK8 & 101306313 & 3 & 19690549..19693371 & 371 & 42.71 & 5.62 & 39.46 & 93.32 & -0.26 & 6 \\
\hline MAPK9 & 101308652 & 3 & 19870360..19873988 & 365 & 41.85 & 5.05 & 42.04 & 95.34 & -0.28 & 6 \\
\hline MAPK10 & 101313449 & 7 & $4574723 . .4578939$ & 373 & 42.67 & 6.08 & 43.9 & 89.38 & -0.33 & 6 \\
\hline MAPK11 & 101313547 & 1 & $9041132 . .9043978$ & 370 & 42.64 & 8.32 & 33.43 & 94.32 & -0.24 & 3 \\
\hline MAPK12 & 101314433 & 2 & $32254545 . .32257169$ & 372 & 42.64 & 6.09 & 38.46 & 95.13 & -0.25 & 3 \\
\hline \multicolumn{11}{|l|}{ MAPKKs } \\
\hline MAPKK1 & 101296494 & 5 & $21018101 . .21019144$ & 347 & 38.73 & 5.64 & 58.27 & 86.54 & -0.19 & 1 \\
\hline MAPKK2 & 101298915 & 6 & $26457958 . .26460120$ & 365 & 40.37 & 9.28 & 60.36 & 76.68 & -0.44 & 1 \\
\hline МАРКKЗ & 101299988 & 1 & 5116387..5119659 & 355 & 39.86 & 6.14 & 51.1 & 95.75 & -0.18 & 8 \\
\hline MAPKK4 & 101300536 & 5 & $9858540 . .9860210$ & 325 & 36.28 & 8.01 & 58.45 & 82.52 & -0.26 & 1 \\
\hline МАРКК5 & 101302771 & 6 & $37368876 . .37372756$ & 518 & 57.53 & 5.34 & 45.36 & 89.63 & -0.15 & 9 \\
\hline МАРКK6 & 101309937 & 5 & 1450708..1451997 & 244 & 26.72 & 6.44 & 56.61 & 80.29 & -0.31 & 1 \\
\hline МАРКК7 & 101310227 & 5 & 1459329..1461416 & 350 & 38.86 & 6.01 & 67.41 & 76.06 & -0.35 & 1 \\
\hline \multicolumn{11}{|l|}{ MAPKKKs } \\
\hline MAPKKK1 & 101291312 & 2 & $32932997 . .32939667$ & 714 & 78.16 & 9.58 & 56.43 & 66.79 & -0.55 & 10 \\
\hline МАРККК2 & 101291614 & 3 & $13958286 . .13959565$ & 311 & 34.68 & 5.59 & 39.15 & 79.9 & -0.31 & 1 \\
\hline МАРКККЗ & 101291671 & 1 & 4101379..4109515 & 973 & 108.54 & 7.03 & 45.49 & 81.31 & -0.42 & 15 \\
\hline МАРККК4 & 101291740 & 6 & $36971098 . .36974966$ & 384 & 42.80 & 6.76 & 36.76 & 75.62 & -0.49 & 6 \\
\hline МАРККК5 & 101292378 & 2 & 18357934..18361624 & 278 & 31.77 & 9.66 & 43.47 & 96.12 & -0.04 & 8 \\
\hline МАРККК & 101292778 & 3 & $8405027 . .8408729$ & 539 & 61.14 & 9.57 & 50.83 & 76.36 & -0.57 & 4 \\
\hline MAPKKKZ & 101292844 & 1 & $4173320 . .4175043$ & 265 & 29.70 & 5.77 & 46.62 & 83.47 & -0.40 & 1 \\
\hline МАРККК 8 & 101293476 & 4 & $7105385 . .7111294$ & 390 & 43.69 & 6.48 & 32.42 & 79.23 & -0.44 & 7 \\
\hline МАРККК9 & 101294141 & 2 & $2588978 . .2594536$ & 1126 & 125.14 & 5.80 & 51.66 & 74.17 & -0.58 & 9 \\
\hline МAPKKK10 & 101294311 & 7 & $2095625 . .2102937$ & 1221 & 135.58 & 5.47 & 47.97 & 72.09 & -0.61 & 9 \\
\hline
\end{tabular}


Table 1. Cont.

\begin{tabular}{|c|c|c|c|c|c|c|c|c|c|c|}
\hline Gene Name & Gene ID & Chr & Location & ORF (aa) & mW (kDa) & pI & Instability Index & $\mathbf{A i}$ & GRAVY & Number of Exons \\
\hline МАРККК11 & 101294663 & 5 & 16790800..16799279 & 511 & 55.61 & 8.61 & 52.95 & 79.77 & -0.45 & 8 \\
\hline MAPKKК12 & 101294665 & 5 & $24653764 . .24659548$ & 591 & 65.24 & 5.68 & 54.8 & 70.93 & -0.59 & 9 \\
\hline МАРККК13 & 101294687 & 6 & $25086652 . .25087498$ & 214 & 24.04 & 6.34 & 49.53 & 82.9 & -0.47 & 2 \\
\hline МАРККК14 & 101295466 & 7 & $2167754 . .2172789$ & 690 & 76.10 & 6.23 & 37.12 & 84.51 & -0.24 & 15 \\
\hline МАРККК15 & 101295905 & 3 & $26006132 . .26009750$ & 415 & 46.98 & 7.91 & 40.22 & 86.7 & -0.43 & 12 \\
\hline МАРККК16 & 101296046 & 7 & 2179758..2185318 & 678 & 75.20 & 5.52 & 39.59 & 87.45 & -0.22 & 15 \\
\hline МAPКKК17 & 101296626 & 2 & $17778744 . .17784528$ & 570 & 63.92 & 5.88 & 55.83 & 84.63 & -0.49 & 16 \\
\hline МАРККK18 & 101297008 & 1 & $11236088 . .11240295$ & 625 & 68.99 & 9.27 & 67.35 & 68.82 & -0.54 & 11 \\
\hline МАРККК19 & 101297162 & 6 & $5243004 . .5248949$ & 670 & 74.51 & 5.97 & 57.02 & 71.43 & -0.53 & 17 \\
\hline MAPKKK20 & 101298508 & 4 & 17684149..17687733 & 434 & 49.07 & 7.79 & 36.92 & 84.06 & -0.48 & 11 \\
\hline МАРКKK21 & 101298797 & 5 & $2958127 . .2962070$ & 404 & 44.58 & 7.51 & 37.14 & 80.37 & -0.39 & 6 \\
\hline MAPKKK22 & 101298822 & 6 & $35785690 . .35790732$ & 457 & 51.78 & 6.10 & 44.73 & 84.07 & -0.46 & 13 \\
\hline MAPKKK23 & 101299949 & 4 & $8553004 . .85558770$ & 1092 & 121.56 & 5.55 & 43.15 & 72.31 & -0.59 & 9 \\
\hline МАРККK24 & 101299957 & 5 & 2999007..3002862 & 347 & 39.54 & 8.04 & 52.15 & 82.65 & -0.33 & 3 \\
\hline MAPКKК25 & 101300060 & 5 & 1036941..1041266 & 697 & 78.06 & 6.49 & 44.46 & 77.91 & -0.58 & 14 \\
\hline МАРККК26 & 101300175 & 1 & 1133811..1138366 & 475 & 53.79 & 9.10 & 44.71 & 86.82 & -0.45 & 13 \\
\hline МАРКKК27 & 101300188 & 7 & 404217..406592 & 344 & 37.94 & 5.76 & 36.34 & 88.46 & -0.07 & 1 \\
\hline МАРККК 28 & 101300232 & 3 & $626166 . .628364$ & 407 & 44.97 & 4.89 & 47.56 & 75.92 & -0.30 & 1 \\
\hline МАРККK29 & 101300748 & 6 & 105416..107101 & 426 & 47.79 & 8.88 & 45.4 & 80.61 & -0.45 & 1 \\
\hline МАРКККЗ30 & 101302206 & 1 & $3358613 . .3363681$ & 995 & 109.61 & 8.87 & 43.56 & 77.84 & -0.47 & 8 \\
\hline МАРККК 31 & 101302247 & 3 & $26940964 . .26947028$ & 717 & 79.93 & 5.70 & 43.53 & 77.98 & -0.33 & 10 \\
\hline МАРККК 32 & 101302307 & 1 & 10029166..10031248 & 415 & 45.28 & 5.03 & 46.91 & 84.36 & -0.14 & 1 \\
\hline МАРКККЗ3 & 101302624 & 3 & $4232964 . .4238052$ & 458 & 51.96 & 7.59 & 49.66 & 90.72 & -0.41 & 12 \\
\hline МАРКKК34 & 101302797 & 7 & 19633448..19634707 & 325 & 36.69 & 8.72 & 39.02 & 80.98 & -0.36 & 1 \\
\hline МАРККК 35 & 101303378 & 7 & 19639527..19640520 & 322 & 36.61 & 8.80 & 40.45 & 87.17 & -0.42 & 1 \\
\hline МАРКККЗ36 & 101303395 & 2 & $22992935 . .22998826$ & 555 & 61.75 & 6.30 & 47.28 & 86.74 & -0.36 & 16 \\
\hline МАРККК 37 & 101303762 & 2 & $14719795 . .14732427$ & 554 & 62.13 & 5.37 & 42.28 & 87.27 & -0.39 & 16 \\
\hline МАРКККЗ & 101303943 & 7 & $620946 . .625977$ & 343 & 37.74 & 6.05 & 38.37 & 87.03 & -0.10 & 3 \\
\hline МАРКККЗ39 & 101304212 & 6 & $25909877 . .25910863$ & 328 & 36.85 & 8.61 & 42.91 & 89.45 & -0.25 & 1 \\
\hline МАРККК 40 & 101304439 & 2 & $16018344 . .16021537$ & 400 & 44.29 & 7.53 & 30.1 & 75.07 & -0.42 & 6 \\
\hline МАРККК 41 & 101305170 & 6 & $21759476 . .21761269$ & 309 & 34.91 & 4.67 & 38.89 & 94.4 & -0.13 & 4 \\
\hline МАРККK42 & 101305413 & 7 & 5759511..5762791 & 444 & 49.43 & 6.92 & 55.58 & 82.79 & -0.26 & 10 \\
\hline МАРКKK43 & 101305446 & 3 & $25233157 . .25239380$ & 777 & 86.22 & 6.83 & 50.65 & 68.51 & -0.66 & 13 \\
\hline МАРККK44 & 101305461 & 4 & 12404607..12409591 & 677 & 74.37 & 7.24 & 47.43 & 74.93 & -0.44 & 17 \\
\hline
\end{tabular}


Table 1. Cont.

\begin{tabular}{|c|c|c|c|c|c|c|c|c|c|c|}
\hline Gene Name & Gene ID & Chr & Location & ORF (aa) & mW (kDa) & pI & Instability Index & $\mathbf{A i}$ & GRAVY & Number of Exons \\
\hline MAPKKK45 & 101305547 & 3 & $15016023 . .15017869$ & 447 & 49.64 & 4.50 & 50.48 & 80.02 & -0.19 & 1 \\
\hline МАРКKК46 & 101305739 & 3 & $5762142 . .5770103$ & 1323 & 145.89 & 5.11 & 46.54 & 75.92 & -0.56 & 9 \\
\hline МАРКKК47 & 101305774 & 6 & 13132618..13140647 & 845 & 93.61 & 5.77 & 44.72 & 81.34 & -0.37 & 16 \\
\hline МAPКKК 48 & 101305797 & 1 & $2243252 . .2248966$ & 1403 & 152.80 & 5.25 & 47.01 & 73.02 & -0.52 & 10 \\
\hline МАРККК 49 & 101307123 & 5 & 17495323..17497199 & 405 & 45.08 & 5.36 & 55.35 & 76.07 & -0.16 & 2 \\
\hline МАРККК50 & 101307418 & 6 & $37601874 . .37604741$ & 346 & 38.84 & 7.21 & 42.97 & 84.91 & -0.24 & 6 \\
\hline МАРККК51 & 101307975 & 3 & $13141362 . .13142841$ & 488 & 53.77 & 4.85 & 49.32 & 79.04 & -0.15 & 1 \\
\hline МАРККК 52 & 101308436 & 2 & $20472173 . .20477216$ & 927 & 101.52 & 5.36 & 43.52 & 83.95 & -0.32 & 13 \\
\hline МАРККК53 & 101308592 & 6 & 15883396..15899615 & 765 & 85.91 & 5.77 & 51.23 & 80.58 & -0.41 & 18 \\
\hline MAPKКK54 & 101308868 & 5 & $1573420 . .1580407$ & 902 & 98.41 & 9.44 & 60.15 & 64.01 & -0.60 & 12 \\
\hline МАРККК55 & 101309867 & 1 & $8084450 . .8090390$ & 572 & 64.91 & 5.69 & 49.85 & 83.5 & -0.43 & 16 \\
\hline МАРККК56 & 101309911 & 3 & $949163 . .951911$ & 374 & 42.66 & 8.96 & 46.65 & 81.1 & -0.42 & 3 \\
\hline МАРККК57 & 101310026 & 5 & 10174217..10182364 & 1034 & 112.94 & 5.53 & 48.91 & 81.21 & -0.44 & 13 \\
\hline МАРККК58 & 101310764 & 7 & $22365118 . .22371514$ & 903 & 97.23 & 9.71 & 65.72 & 62.98 & -0.59 & 12 \\
\hline МАРККК59 & 101312454 & 5 & $26796369 . .26801049$ & 390 & 44.24 & 5.57 & 43.6 & 83.49 & -0.40 & 6 \\
\hline МАРККК 60 & 101312659 & 6 & $20974416 . .20976740$ & 433 & 49.51 & 5.10 & 37.22 & 83.79 & -0.48 & 5 \\
\hline МАРККК61 & 101312816 & 3 & $25255805 . .25265535$ & 794 & 89.06 & 6.09 & 50.14 & 76.49 & -0.45 & 17 \\
\hline МАРККК 62 & 101312898 & 2 & $9859412 . .9866665$ & 1192 & 130.83 & 5.15 & 48.2 & 80.05 & -0.44 & 9 \\
\hline МАРККК63 & 101313105 & 3 & 25269938..25276589 & 710 & 80.27 & 7.32 & 41.81 & 78.39 & -0.48 & 13 \\
\hline МАРККК 64 & 101313212 & 5 & $5764644 . .5768035$ & 350 & 39.78 & 6.43 & 46.69 & 83.09 & -0.30 & 7 \\
\hline МАРККК 65 & 101313251 & 1 & $16064274 . .16069495$ & 618 & 67.06 & 9.22 & 52.62 & 67.38 & -0.53 & 11 \\
\hline МАРККК 66 & 101313299 & 3 & $26914066 . .26919397$ & 239 & 27.17 & 9.23 & 30.57 & 96.69 & -0.21 & 11 \\
\hline МАРККК 67 & 101315161 & 6 & $6707178 . .6711235$ & 358 & 40.09 & 9.03 & 39.93 & 88.02 & -0.30 & 6 \\
\hline МАРККК 68 & 101315443 & 6 & $93407 . .100195$ & 918 & 100.48 & 5.91 & 44.43 & 77.24 & -0.45 & 13 \\
\hline МАРККК 69 & 105349270 & 7 & $5764174 . .5768902$ & 438 & 47.17 & 10.09 & 59.37 & 77.92 & -0.48 & 10 \\
\hline МАРККК70 & 105349796 & 2 & 18355556..18356787 & 219 & 24.73 & 8.73 & 42.83 & 89.45 & -0.21 & 4 \\
\hline МАРККК71 & 105351460 & 1 & 10823118..10824804 & 351 & 39.06 & 4.97 & 47.76 & 73.59 & -0.36 & 1 \\
\hline МАРККК 72 & 105351574 & 5 & $13162396 . .13164156$ & 298 & 33.63 & 6.84 & 50.69 & 82.08 & -0.43 & 1 \\
\hline МАРККK 73 & 105353223 & 7 & $5144013 . .5149034$ & 682 & 77.82 & 8.15 & 44.6 & 87.76 & -0.40 & 13 \\
\hline \multicolumn{11}{|l|}{$M A P K K K K s$} \\
\hline MAP4K1 & 101308962 & 4 & $17222313 . .17230075$ & 821 & 90.20 & 5.21 & 47.82 & 71.06 & -0.54 & 18 \\
\hline
\end{tabular}


The division of the FvMAPK sequences into four distinct groups was consistent with previous reports [14,37]. FvMAPK1, FvMAPK9 and FvMAPK10 clustered within Group I. MAPKs are involved in both abiotic stress responses and cell division in A. thaliana $[23,24]$. FvMAPK5 and FvMAPK8 belonged to Group II, together with AtMPK3 and AtMPK6, and Group III includes FvMAPK11 and FvMAPK12 and members from this group in other plant species are known to be regulated by both biotic and abiotic stresses [25]. The largest group was Group IV, which included five members (FvMAPK2, FvMAPK3, FvMAPK4, FvMAPK6 and FvMAPK7) with the TDY motif in their T-loop and the absence of the C-terminal CD domain, which is consistently present in members of the other MAPK groups.

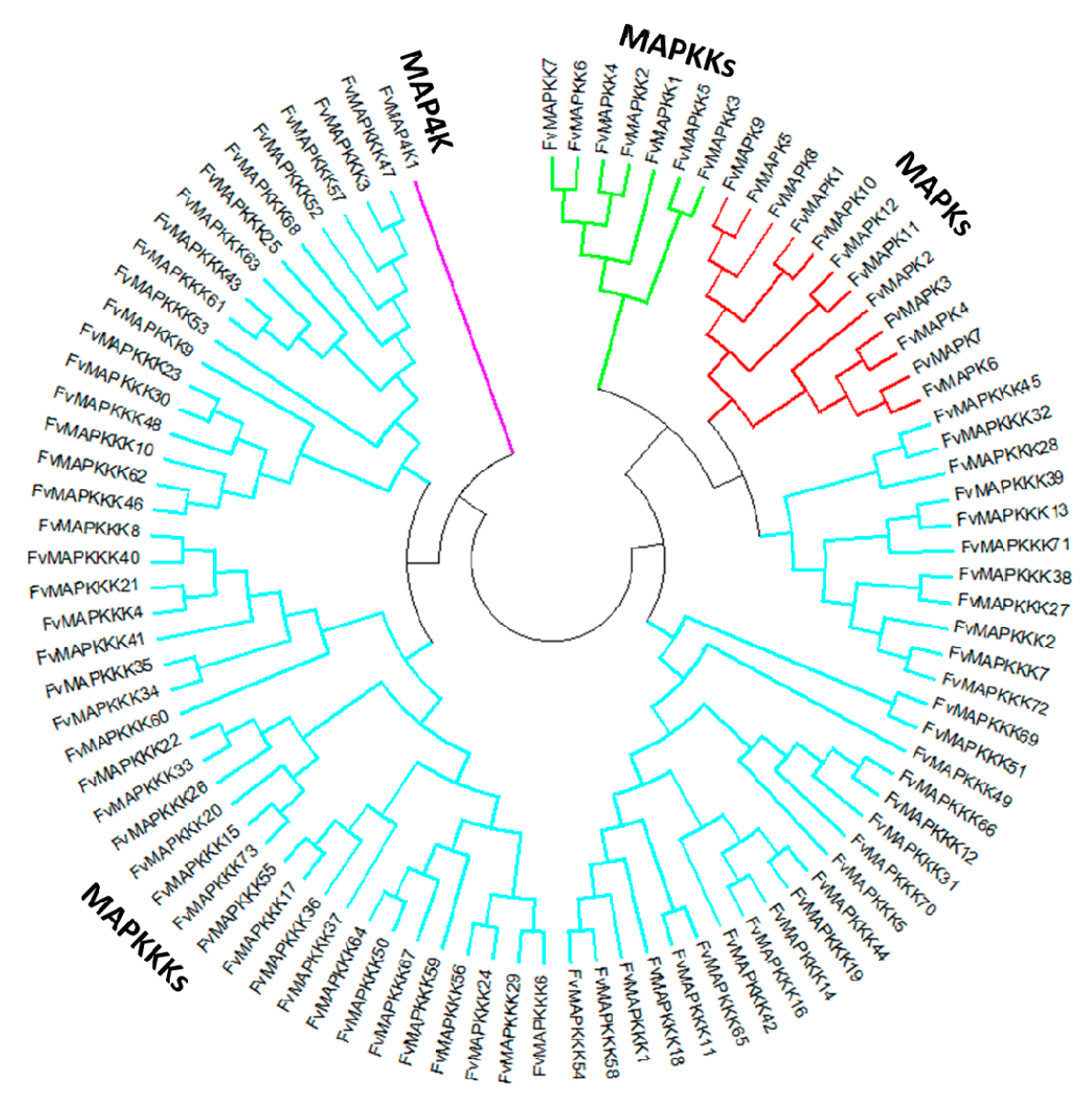

Figure 2. Phylogenetic relationships between strawberry MAPK cascade proteins. The abbreviations of MAPK cascade proteins are as follows: MAPK, Mitogen-activated Protein Kinase, red lines; MAPKK, MAPK Kinase, green lines; MAPKKK, MAPKK Kinase, blue lines; MAP4K, MAPKKK Kinase, purple lines. 

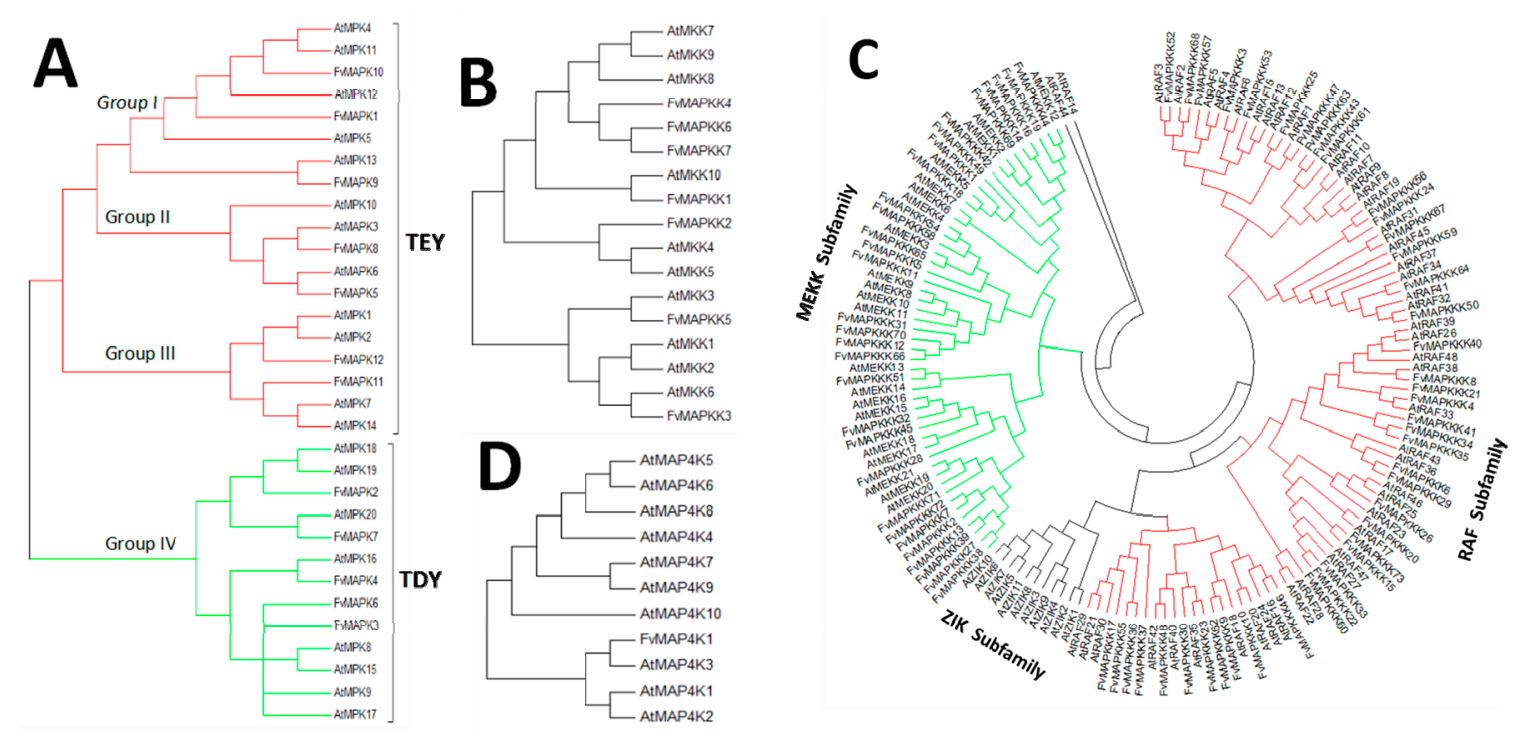

Figure 3. Phylogenetic relationships between MAPK cascade proteins from Arabidopsis thaliana and strawberry: (A) phylogenetic relationship between $A$. thaliana and FvMAPK proteins, red lines show TEY group; (B) phylogenetic relationship between $A$. thaliana and FvMAPKK proteins, green lines show TDY group; and (C) phylogenetic relationship between $A$. thaliana and FvMAPKKK proteins. MAPKKK forms the largest group of MAPK cascade proteins with 73 members classified into two subfamilies, MEKK (green lines) and Raf (red lines), which contain 30 and 43 genes in the Fragaria vesca and $A$. thaliana genomes. (D) Phylogenetic relationship between $A$. thaliana and strawberry MAPKKKK proteins.

Seven members of the MAPKK subfamily, similar to the AtMAPKKs, could also be divided into four groups: FvMAPKK1, FvMAPKK3 and FvMAPKK5 were most similar to AtMPKK10, AtMPKK6 and AtMPKK3, respectively, while FvMPKK2 is homologous to AtMPKK4/AtMPKK5. FvMPKK4, -6 and -7 and AtMPKK7, -8 , and -9 clustered into the same group (Figure $3 \mathrm{~B}$ ).

MAPKKKs are activated by either phosphorylation by other MAPKKK kinases or by $G$ proteins and $G$ protein-coupled receptors. With 73 members, the MAPKKK subfamily represented the largest subfamily, of a similar size to that in rice ( 75 members), larger than that in grape (62 members), but smaller than that in A. thaliana ( 80 members). Generally, the members of this subfamily can be classified into three groups: the MEKK subfamily, the ZIK subfamily and the Raf subfamily; however, only two groups were identified in the strawberry genome. In total, there were 30 FvMAPKKKs in the MEKK subfamily, and 43 in the Raf subfamily with no ZIK members identified (Figure 3C).

Although several MAP4Ks have been reported in plant genomes based on phylogenetic analyses of their kinase domain, little is known about the roles of MAPKKKKs in plants. Only one member was identified in F. vesca (Figure 3D).

\subsection{Expression Profiles of FvMAPKs and FvMAPKKs in Different Organs and Fruit Developmental Stages}

Expression profiles provide some useful clues to gene functions. To investigate the putative involvement of FvMAPK and FvMAPKK genes in strawberry growth and development, the expression patterns of all of these genes were analyzed under normal growth conditions in four different organs (leaves, roots, stems and fruits) at various developmental stages. Of the 19 predicted genes, all were expressed in at least one of the four organs (Figure 4). FvMPK7 and FvMPK10 showed high expression in leaves and FvMPK10 and FvMPK11 were highly expressed in fruits. FvMAPKK2, FvMAPKK4 and FvMAPKK5 were expressed in all organs, while FvMAPKK6 and FvMAPKK7 were only expressed in leaves, and FvMAPKK1 and FvMAPKK3 did not express any of the different organs under normal growth conditions. 


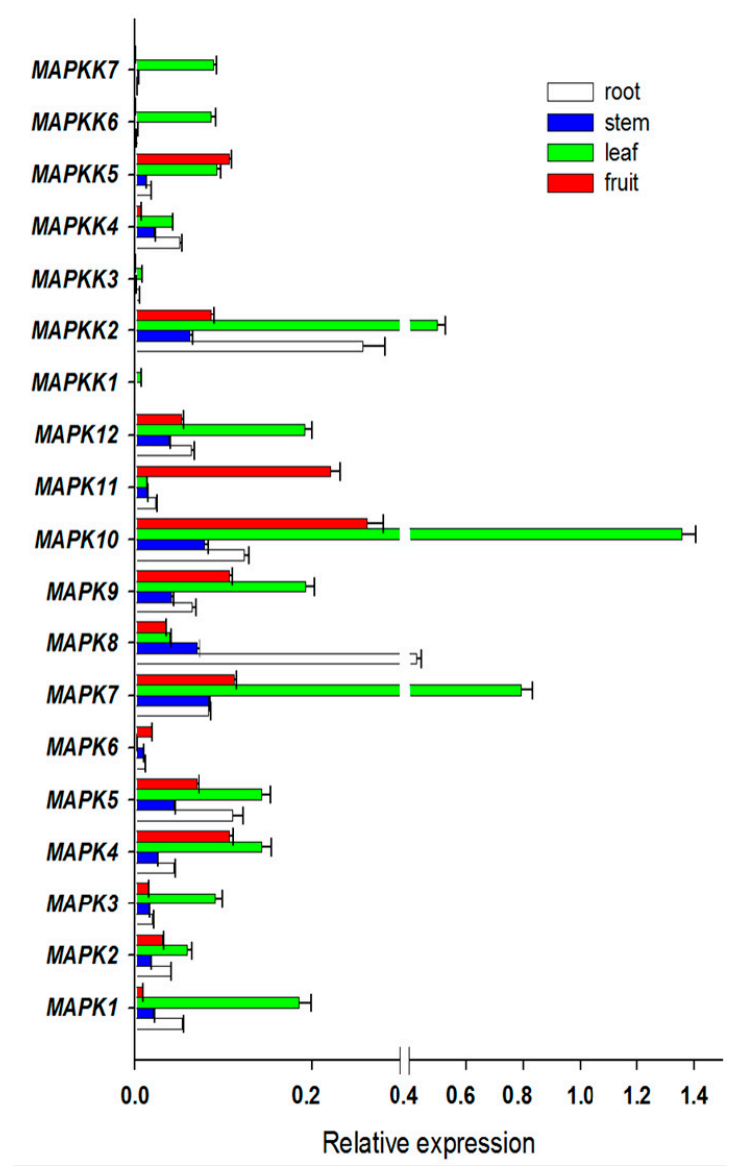

Figure 4. Expression patterns of FvMPKs and FvMPKKs in different organs. $X$-axis is the relative expression, while $Y$-axis is MAPK and MAPKK genes; white box, root; blue box, stem; green box, leave; red box, fruit.

We also determined the expression of FvMAPK cascade genes in different fruit developmental stages. The transcript levels of FvMAPK2 and FvMAPK12 were lower than any other of the genes in all the different fruit developmental stages. For the remaining 10 genes, the expression patterns could be roughly divided into three categories: FvMAPK3, FvMAPK4 and FvMAPK11 showed the same expression patterns, which increased through development. FvMAPK1, FvMAPK9 and FvMAPK10 expression, however, declined during fruit development. Finally, there were six genes (FvMAPK5, FvMAPK6, FvMAPK7 and FvMAPK8) that showed a high expression in the early stages, then a decrease and later an increase in the later stages of fruit development. In the FvMAPKKS subfamily, only FvMAPKK2, FvMAPKK4 and FvMAPKK5 were expressed in fruits at a detectable level, and they had the same expression patterns, which gradually rose through fruit development (Figure 5). Since F. vesca is a new model for investigating non-climacteric fruit development and ripening, we focused on determining the expression profiles of the FvMAPKKK subfamily to different fruit developmental stages. The expression profiles of the FvMAPKKK genes revealed a much higher expression in early stages than in later ripening or senescing stages, indicating that they are most likely related to signal transduction during development in metabolically active tissues (Figure 6). Some FvMAPKKK transcripts showed higher levels in earlier than later stages of fruit development, while others showed the opposite pattern. This information can be important for further investigation of the signal transduction pathways involved in the regulation of fruit development and ripening, in which different MAPKKK subfamily members may be involved. 


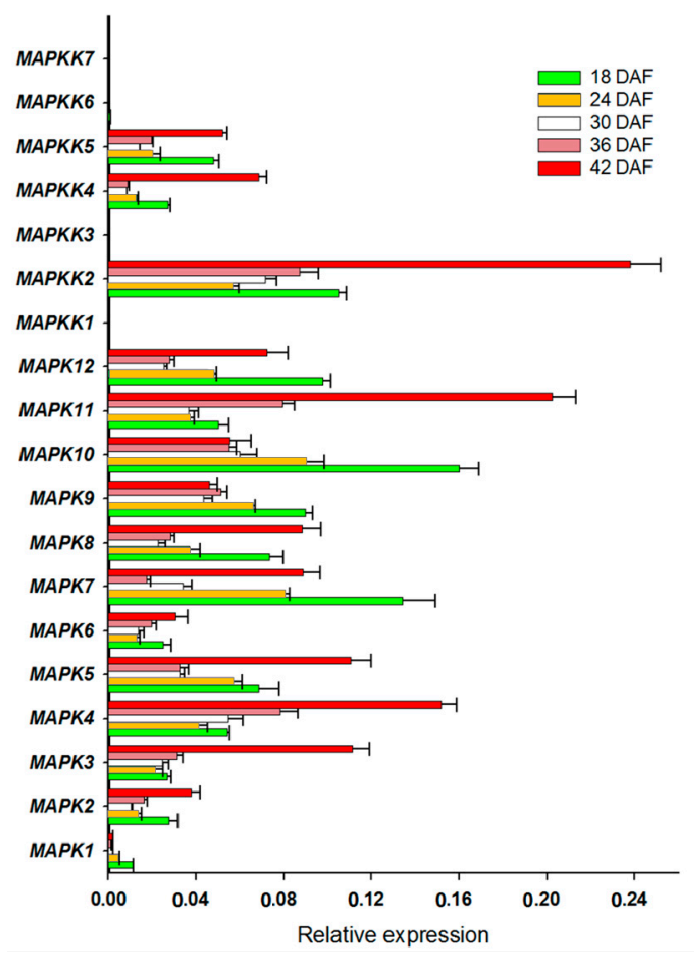

Figure 5. FvMPK and FvMPKK expression profiles in different fruit developmental stages. $X$-axis is the relative expression, while $Y$-axis is MAPK and MAPKK genes; 18-42 DAF, five developmental stages of days after flowering.

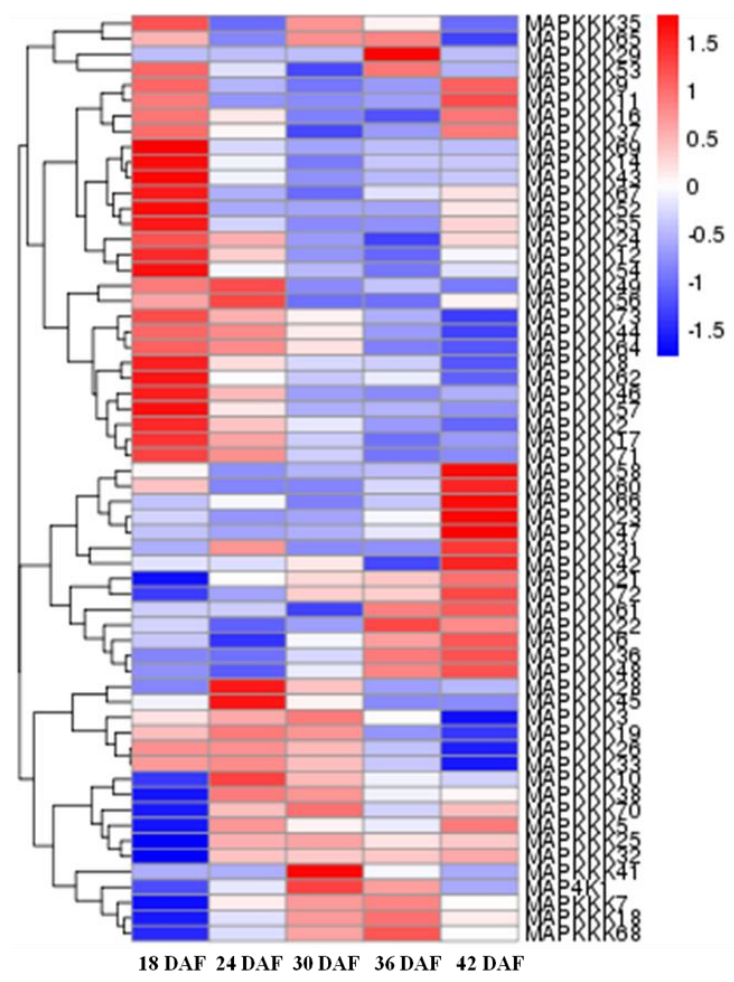

Figure 6. RNA-seq data showing FvMAPKKK gene expression in different fruit developmental stages. The gene expression levels were showed by the color box from blue to red indicating from low to high for each gene; $18-42$ DAF, five developmental stages of days after flowering. 
2.3. Gene Expression Profiles of FvMAPKs and FvMAPKKs in Response to Hormones and Abiotic Stresses in F. vesca Leaves

We investigated whether salt, drought, low temperature and exogenous application of the hormones indole acetic acid (IAA) and abscisic acid (ABA) would induce expression of the FvMAPK and FvMAPKK genes in seedling leaves using qRT-PCR analysis. After cold treatment, most of the tested genes showed a large expression increase $48 \mathrm{~h}$ after treatment. Among them was MAPK2, whose expression increased in early stages before decreasing. In general, drought stress resulted in the induction of the greatest number of genes and a significantly improved in the process 12 days. In response to salt stress, the expression of five FvMAPK genes (FvMAPK5, -9, -10,-11 and -12) and three FvMAPKK genes (FvMAPKK1, -3 and -5) increased. Interestingly, the transcript levels of FvMAPKK3 were specifically activated by salt stress and not by the other treatments. The expression of FvMAPK3 and -12 and FvMAPKK4, -5 and -6 was activated by ABA, while the IAA treatment only resulted in a change in FvMAPKK4 expression, which was up-regulated two days after treatment (Figure 7).

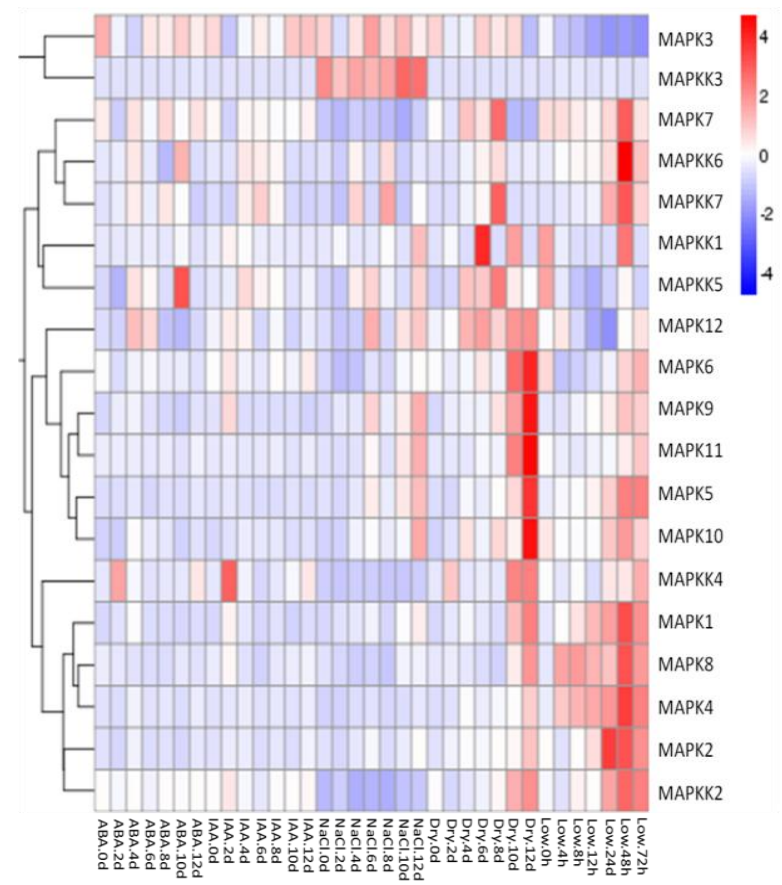

Figure 7. Expression patterns of FvMPK and FvMPKK genes after different stress and hormone treatments of leaves in Fragaria vesca. Leaves were harvested every two days (0, 2, 4, 6, 8, 10 and 12 days) after treatment: Abscisic acid (ABA) $(100 \mu \mathrm{M})$, indole-3-acetic acid (IAA) $(100 \mu \mathrm{M}), \mathrm{NaCl}$ $(100 \mathrm{mM})$ and drought treatments. Leaves from the low temperature treatment were collected at $0,4,8$, $12,24,48$ and $72 \mathrm{~h}$ after cold stress application.

2.4. Expression Patterns of FvMAPK and FvMAPKK Genes in Response to Sucrose, Hormones and Abiotic Stresses in F. vesca Fruits

The expression patterns of the FvMAPK and FvMAPKK genes at an early stage (18 DAF: days after flowering) and a late stage (36 DAF) of fruit development in response to exogenous IAA, ABA and sucrose treatment and drought, high temperature or low temperature stresses were also examined by qRT-PCR analyses. Almost all showed a higher expression level in the early than in the later stage. It was interesting that the transcript levels of almost all the genes were up-regulated in response to IAA, drought and low temperature treatment at the early stage of fruit development (18 DAF). During low temperature stress, the expression of 17 of the 19 genes increased significantly at 18 DAF, while the transcript levels of FvMAPK3, FvMAPKK1, FvMAPKK3, FvMAPKK6, and FvMAPKK7 were significantly up-regulated by high temperature treatment, even though the expression of FvMAPKK1, 
FvMAPKK3, FvMAPKK6, and FvMAPKK7 could not be detected under normal growth conditions (Figure 8).

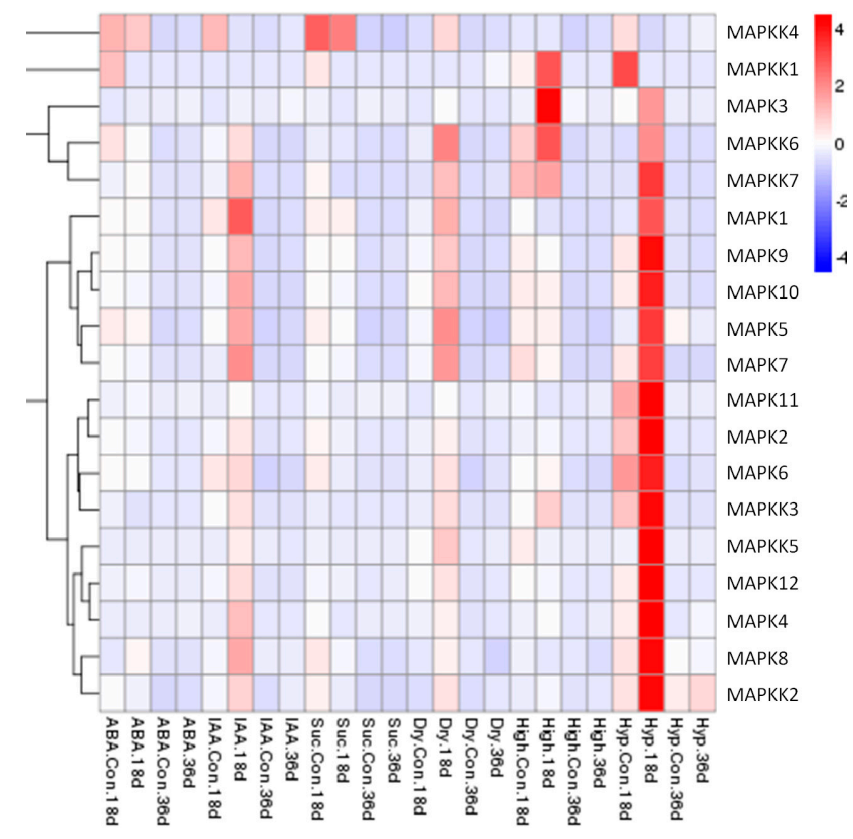

Figure 8. Expression patterns of FvMPK and FvMPKK genes in fruits after different stress pre-treatments. Red and blue boxes indicate high and low expression levels, respectively, for each gene. Six treatments: Abscisic acid (ABA), $100 \mu \mathrm{M}$; indole-3-acetic acid (IAA), $100 \mu \mathrm{M}$; Suc, sucrose $50 \mu \mathrm{M}$; Dry, drought treatment; High, high temperature $\left(40{ }^{\circ} \mathrm{C}\right)$; Low, low temperature $\left(4{ }^{\circ} \mathrm{C}\right)$; Con., controlled trials of fruits without any pre-treatments; $18 \mathrm{~d}$., $18 \mathrm{DAF}$ fruits; $36 \mathrm{~d}$., $36 \mathrm{DAF}$ fruits.

\section{Discussion}

Although MAPKs have been studied in other plant species, the FvMAPK cascades have not yet been comprehensively studied. Here, we identified 12 FvMAPK, 7 FvMAPKK, 73 FvMAPKKK and 1 FvMAPKKKK genes. There are only 12 MAPK and 7 MAPKK members in the strawberry genome, while at least 20 MAPK genes and 10 MAPKK genes have been identified in the $A$. thaliana genome, even though the genome size of $F$. vesca $(240 \mathrm{Mb})$ is approximately twice that of the $A$. thaliana genome $(\sim 125 \mathrm{Mb})$. The numbers are more comparable to those in $V$. vinifera $(\sim 400 \mathrm{Mb})$, where 14 MAPK and 5 MAPKK members have been identified [1,42]. With 73 members, the MAPKKK subfamily is similar in size to that of rice (75 members), larger than that of grapevine (62 members) but smaller than that of A. thaliana ( 80 members). Only a few MAP4K genes have been identified in plant genome based on phylogenetic analysis of the kinase domain $[5,15]$. At least 10 protein kinases can be phylogenetically characterized as MAP4K in the A. thaliana and rice genomes, but little is known about their roles. Only one MAP4K member was identified in the $F$. vesca genome, but the ORF showed strong similarity to ScMAP4K1 from the wild potato species Solanum chacoense, which is known to play important roles in ovule, seed, and fruit development [44], and a similar role is therefore possible in strawberry.

The phylogenetic analysis showed that the FvMAPKs can be divided into four groups based on the conserved residues of the TEY/TDY motifs in the activation loop region (T-loop) between the kinase subdomains VII and VIII [9]. Members of the FvMAPK subfamily showed 24-89\% identity to each other FvMAPKs, and their full-length sequences ranged from 365 to 691 amino acids. The difference in length is usually due to variation in the length of the domain or a variable number of introns, and may indicate the absence or presence of motifs, which can affect the functional specificity. There are 10 and 7 MAPKK members in $A$. thaliana and $F$. vesca, respectively. The full length FvMAPKK proteins ranged in size from 244 to 518 amino acids, and shared $25-42 \%$ similarity with each other. The members 
of the FvMAPKKK subfamily were distributed to all the chromosomes and shared $12-34 \%$ identity with each other, with a sequence length ranging from 214 to 1403 amino acids. A kinase domain in the C-terminal and a long regulatory domain in the $\mathrm{N}$ - terminal region were identified in most FvMAPKKKs, suggesting that the specific long regulatory domain exited in the N-terminal of the RAF subfamily may involve in specify the kinase activity and regulating protein interaction [45]. It is interesting that no FvMAPKKK was found that belonged to the ZIK subfamily, which in other species has members with a conserved GTPEFMAPE (L/V) Y signature. The absence of the characteristic ZIK subfamily feature in $F$. vesca might suggest the presence of a slightly modified RAF domain, instead of the typical ZIK domain as reported in Vitis [42].

As the last two steps of the MAPK cascade, MAPK and MAPKK link upstream kinases and downstream substrates. As dual-specificity kinases, MAPKKs can be activated and phosphorylated by MAPKKKs via phosphorylation of Thr/Ser residues, while MAPKKs also phosphorylate the downstream MAPKs, and activated MAPKs can phosphorylate different substrates, including other transcription factors, kinases, and cytoskeleton binding proteins [3]. The MAPK cascade protein (MAP4K-MAPKKK-MAPKK-MAPK) family is large and the functions of the various members can be complex. Though there are many members identified in the MAPKKK and MAP4K subfamilies, little is known about the MAPKs and MAPKKs. In this study, we mainly focused our gene expression pattern analysis on the MAPK and MAPKK genes. We evaluated the expression patterns of all of the predicted members of the FvMAPK and FvMAPKK subfamily in different strawberry organs and developmental stages. The expression of most of the FvMAPK and FvMAPKK genes was detected in the strawberry organs investigated, possibly reflecting their involvement in a common metabolic and/or developmental process. Among them, FvMAPK7, FvMAPK10 and FvMAPKK2 showed significantly higher expression in leaves than in other organs, and FvMAPKK6 and FvMAPKK7 were specifically expressed in leaves, whereas the FvMAPK6 transcripts were not be detected in leaves, indicating different functions for divergent family members.

Stress-specific increased MAPK genes and kinase activity has been identified when plants are suffering from a variety of abiotic stresses, including drought, cold, high salinity, ozone, UV irradiation and oxidative stress [46-49]. Plant hormones were detected playing a role in trigger stress responses and developmental pathways with other signaling molecules [46,50-52]. The components of MEKK1, MKK2, MPK4, and/or MPK6 respond to drought, salt, or cold stressed were characterized in A. thaliana [22,47]. We studied the interaction between hormone and gene expression patterns in strawberry fruit. FvMAPK5 and FvMAPK8 belong to group II, which contains well-characterized $M A P K$ genes including AtMAPK3 and AtMAPK6. It has been reported that AtMAPK3 can be activated in response to abiotic stresses and pathogens, and AtMAPK6 also plays a role in abiotic and biotic stresses $[10,39,53,54]$. Similarly, we speculate that FvMAPK5 and FvMAPK8 are important for abiotic or biotic stress responses due to their transcriptional activation by cold and drought. FvMAPK1, FvMAPK9 and FvMAPK10 are clustered in Group I, while also includes AtMAPK4, AtMAPK5, AtMAPK11, AtMAPK12 and AtMAPK13. AtMPK4 and its upstream MAPKK, AtMKK2, are involved in both biotic and abiotic stresses. The expression patterns of FvMAPK1, FvMAPK9 and FvMAPK10 were similar in fruits but not in leaves, suggesting different functions depending on the organ [55].

In A. thaliana, AtMPKK3 is up-regulated in response to ABA [46], and FvMPKK5, which showed the highest homology to AtMPKK3, showed strong activation by ABA in leaves, suggesting a similar function. Interestingly, AtMKK1/AtMKK2, which are activated by salt, drought, and cold stresses [22,23], and their ortholog FvMAPKK3, showed specific activation by salt stress in leaves and significant expression changes due to cold and heat stress. 


\section{Materials and Methods}

\subsection{Identification of Potential MAPK Cascade Gene Family Members in Strawberry}

To identify a complete list of strawberry MAPK cascade genes, we used two public databases: the National Centre for Biotechnology Information (NCBI; http:/ / www.ncbi.nlm.nih.gov /) and F. vesca BioView Gene Model Database (https: / / strawberry.plantandfood.co.nz/).

\subsection{Phylogenetic Analysis of A. Thaliana and the Strawberry MAPK Cascade Genes}

Phylogenetic analysis was performed using the MEGA 5.1 software (USA) and the neighbor-joining method. Bootstrap values were calculated for 1000 iterations [56,57]. The A. thaliana MAPK cascades gene family database was obtained from TAIR (The A. thaliana Information Resource, http: / / www.arabidopsis.org) and used for comparative analysis.

\subsection{Plant Material and Fruit Pre-Treatments}

F. vesca ("Hawaii 4") plants were grown on a growth chamber at $22 \pm 1{ }^{\circ} \mathrm{C}$ in a $13 / 11 \mathrm{~h}$ dark/light photoperiod. Fruit samples were harvested every 6 days starting of the 18 days after flowering $(18,24$, 30, 36 and $42 \mathrm{DAF})$. At each developmental stage, ten representative fruits were sampled, and tissues were immediately frozen in liquid nitrogen and stored at $-80{ }^{\circ} \mathrm{C}$ until further use. In order to obtain different pre-treatment experimental fruits, two stages (18 and 36 DAF) were selected for sucrose and hormone treatments. The fruits were cut in half longitudinally, and half was used as a control while the other half was used for processing. The different treatments used in this work were indole-3-acetic acid (IAA), abscisic acid (ABA) and sucrose, at a concentration of 100, 100 and $50 \mu \mathrm{M}$ respectively. The high and low temperature was $40^{\circ} \mathrm{C}$ and $4{ }^{\circ} \mathrm{C}$. All other experiments were performed at $25^{\circ} \mathrm{C}$.

\subsection{The Processing of Strawberry Leaves under Different Stress and Hormone Treatments}

To investigate the induced expression patterns of the FvMAPK and FvMAPKK genes in seedling leaves in response to various treatments, 30 days old soil grown seedlings were used. For salt stress treatment, seedlings were irrigated in $100 \mathrm{mM} \mathrm{NaCl}$, collected 2, 4, 6, 8, 10 and 12 days after salt treatment of leaves, without salt stress as control. For the drought stress treatment, all plants were stopped to water after full irrigation watering, then clipping the leaves in 2, 4, 6, 8, 10 and 12 days and no drought stress as the control respectively. For the cold treatment, seedlings were maintained at $0{ }^{\circ} \mathrm{C}$ and leaf material collected at 4, 8, 12, 24, 48 and $72 \mathrm{~h}$. Leaves cultivated in a growth chamber at $22 \pm 1{ }^{\circ} \mathrm{C}$ were used as controls. For the hormone treatments, plants were sprayed with solutions containing $100 \mu \mathrm{M}$ ABA or $100 \mu \mathrm{M}$ IAA, then leaves were collected after 2, 4, 6, 8, 10 and 12 days. Plants that had not been sprayed served as the controls. Samples were immediately frozen in liquid nitrogen, and stored at $-80^{\circ} \mathrm{C}$.

\subsection{RNA Extraction and Real-Time PCR Analysis}

Total RNA was isolated from strawberry fruits harvested at 18, 24, 30, 36 and 42 DAF using the Plant RNA Kit (Omega, USA) according to the manufacturer's instructions, and total RNA was reverse transcribed into cDNA using the Invitrogen reverse transcription kit (SuperScriptIII Reverse Transcriptase, USA). Real-time PCR was performed to confirm gene expression patterns using a Light Cycler ${ }^{\circledR} 96$ SW1.1 Real Time PCR System (Roche, Germany), with SYBR-Green (Takara, Dalian, China). The primer sequences used are designed based on gene sequences and the Beacon designer software and are shown in Table 2 in this study. Each reaction consists of $5 \mu \mathrm{L} \mathrm{SYBR}, 3.5 \mu \mathrm{L}$ ddH ${ }_{2} \mathrm{O}, 1 \mu \mathrm{L}$ diluted

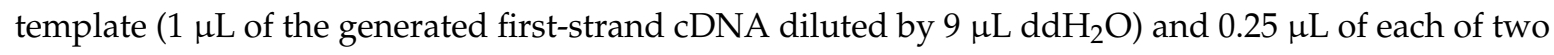
gene specific primers. Thermal cycling conditions were $95^{\circ} \mathrm{C}$ for $10 \mathrm{~min}$, then 40 cycles at $95^{\circ} \mathrm{C}$ for $20 \mathrm{~s}, 54^{\circ} \mathrm{C}$ for $20 \mathrm{~s}, 72{ }^{\circ} \mathrm{C}$ for $20 \mathrm{~s}$. 
Table 2. Primer sequence information.

\begin{tabular}{|c|c|c|}
\hline Gene & Sequences $5^{\prime} \rightarrow 3^{\prime}$ & Annealing Temperature \\
\hline MAPK1 & $\begin{array}{l}\text { F: TAGCAAGAACAACATCCGAGAC } \\
\text { R: GCTCCAGGCGACATATTAGG }\end{array}$ & $54^{\circ} \mathrm{C}$ \\
\hline MAPK2 & $\begin{array}{l}\text { F: ACACCTACACTAGAGACCATC } \\
\text { R: TGCCTTCCGTTCCATTCAT }\end{array}$ & $54^{\circ} \mathrm{C}$ \\
\hline MAPK3 & $\begin{array}{l}\text { F: CCTTGGTGGACGGTGTTC } \\
\text { R: GGTGGTGGTGGATTGTGG }\end{array}$ & $54^{\circ} \mathrm{C}$ \\
\hline MAPK4 & $\begin{array}{l}\text { F: CTTATCTTGAGGAGCACTATGGAA } \\
\text { R: CGTAATACTGAGCCGACAACT }\end{array}$ & $54{ }^{\circ} \mathrm{C}$ \\
\hline MAPK5 & $\begin{array}{l}\text { F: GCGGCAGATTCATCCAGTA } \\
\text { R: TGACAATGCTCCTCAGATAGA }\end{array}$ & $54{ }^{\circ} \mathrm{C}$ \\
\hline MAPK6 & $\begin{array}{l}\text { F: GCATCTCCACTTCTACATCTTCA } \\
\text { R: TGCCAATCACTTCTTGTATCTCA }\end{array}$ & $54{ }^{\circ} \mathrm{C}$ \\
\hline MAPK7 & $\begin{array}{l}\text { F: ACCGAAGGACGCTTGTTAG } \\
\text { R: AGCAGCAGCAGAACCAAT }\end{array}$ & $54^{\circ} \mathrm{C}$ \\
\hline MAPK 8 & $\begin{array}{l}\text { F: CATCGTCTGCTCGGTGTT } \\
\text { R: GCTCGGCTTCAAGTCTCTAT }\end{array}$ & $54{ }^{\circ} \mathrm{C}$ \\
\hline МAPK9 & $\begin{array}{l}\text { F: CCACCAGATAAGGAGAACTTCAAT } \\
\text { R: CGATACCAACGAGTGACAACA }\end{array}$ & $54{ }^{\circ} \mathrm{C}$ \\
\hline MAPK10 & $\begin{array}{l}\text { F: AGTGATAATGCCCGAAGATATGT } \\
\text { R: GGATTGAACTTGACCGACTC }\end{array}$ & $54{ }^{\circ} \mathrm{C}$ \\
\hline MAPK11 & $\begin{array}{l}\text { F: GAGAGGAGCATACGGTGTTG } \\
\text { R: AGTTAGCATTGATGAGCAGGTT }\end{array}$ & $54^{\circ} \mathrm{C}$ \\
\hline MAPK12 & $\begin{array}{l}\text { F: CTGTGCTGCGATAACTATGGA } \\
\text { R: GGTGTTGGAGTGCTTCAG }\end{array}$ & $54^{\circ} \mathrm{C}$ \\
\hline MAPKK1 & $\begin{array}{l}\text { F: TGACTCTCCAGGCATTATTGAA } \\
\text { R: GCCACGCCAGAGATTACC }\end{array}$ & $54^{\circ} \mathrm{C}$ \\
\hline МAPKK2 & $\begin{array}{l}\text { F: CTCCACAGACGGCACATC } \\
\text { R: GGCGGCTGAGACATACAAAT }\end{array}$ & $54^{\circ} \mathrm{C}$ \\
\hline MAPKKЗ & $\begin{array}{l}\text { F: GAAAGGAAGTGGTGGTGTAGT } \\
\text { R: GCAAGATATGGTTCAAGAATTGTCT }\end{array}$ & $54{ }^{\circ} \mathrm{C}$ \\
\hline MAPKK4 & $\begin{array}{l}\text { F: ACTGCTCCTCCTCGTCTT } \\
\text { R: CGTGCCTTGCTGTTTGA }\end{array}$ & $54{ }^{\circ} \mathrm{C}$ \\
\hline MAPKK5 & $\begin{array}{l}\text { F: GGATGAAGGACTTGGCAGAT } \\
\text { R: AACACCGTCTCCACATATAAGG }\end{array}$ & $54^{\circ} \mathrm{C}$ \\
\hline МАРКК 6 & $\begin{array}{l}\text { F: CCACCTCCACCACTTACG } \\
\text { R: GGCGATCTTGACCTCATTCT }\end{array}$ & $54^{\circ} \mathrm{C}$ \\
\hline MAPKK7 & $\begin{array}{l}\text { F: CTCCACCACTTACGCTCTC } \\
\text { R: GACCTCGTTCTTGTTGTTCATT }\end{array}$ & $54{ }^{\circ} \mathrm{C}$ \\
\hline Actin & $\begin{array}{l}\text { F: TGGGTTTGCTGGAGATGAT } \\
\text { R: CAGTTAGGAGAACTGGGTGC }\end{array}$ & $54{ }^{\circ} \mathrm{C}$ \\
\hline
\end{tabular}

\section{Conclusions}

MAPK cascades are responsible for protein phosphorylation during signal transduction events, and typically classify as three protein kinases: MAPK, MAPK kinase, and MAPK kinase kinase. Our study provides a comprehensive overview of the 12 FvMAPK, 7 FvMAPKK, 73 FvMAPKKK and 1 FvMAPKKKK genes identified in the $F$. vesca genome. The identification of MAPK cascade proteins and a comparative analysis with the $A$. thaliana MAPK cascade proteins indicated that the MAPK 
cascade genes have been conserved during evolution and suggests that MAPK cascades play vital roles in fruit development and in responses to abiotic stresses and hormone signal transduction. Among these genes, FvMAPK7, FvMAPK10 and FvMAPKK2 showed significantly higher expression in leaves than in other organs, and FvMAPK11 and FvMAPKK2 have an up-regulation and significantly improved in the later stage of fruit development. For various hormones and stresses, cold stress has great influence on gene expression. This information will be helpful in the physiological and biochemical functional characterization of the MAPK cascades in strawberry.

Acknowledgments: We thank Jocelyn Rose from Cornell University to help to discuss the experiment and revise our manuscript. This work was supported by the National Natural Science Foundation of China (Grant No. 31370323), the High-Caliber Talents Project of Beijing Municipal Organization Department (2014000026833ZK18), the Beijing Municipal Education Commission (CEFF-PXM2017_014207_000033) and the Beijing Natural Science Foundation and Scientific Research Key Program of Beijing Municipal Commission of Education (KZ20130020018).

Author Contributions: Heying Zhou and Yu Xing designed and initiated this study. Heying Zhou and Suyue Ren carried out the bioinformatics analyses. Yuanfang Han and Yu Xing participated in qRT-PCR analyses. Heying Zhou and Yu Xing wrote the manuscript. Ling Qin and Qing Zhang helped in discussions of the manuscript. All authors read and approved the final manuscript.

Conflicts of Interest: The authors declare no conflict of interest.

\section{References}

1. Baluška, F.; Mancuso, S. Signaling in Plants, Signaling and Communication in Plants; Springer-Verlag: New York, NY, USA; Berlin/Heidelberg, Germany, 2009; pp. 51-69.

2. Hamel, L.P.; Nicole, M.C.; Sritubtim, S.; Morency, M.J.; Ellis, M.; Ehlting, J. Ancient signals: Comparative genomics of plant MAPK and MAPKK gene families. Trends Plant Sci. 2006, 11, 4. [CrossRef] [PubMed]

3. Rodriguez, M.C.; Petersen, M.; Mundy, J. Mitogen-activated protein kinase signaling in plants. Annu. Rev. Plant Biol. 2010, 61, 621-649. [PubMed]

4. Asai, T.; Tena, G.; Plotnikova, J.; Willmann, M.R.; Chiu, W.L.; Gomez-Gomez, L. MAP kinase signalling cascade in Arabidopsis innate immunity. Nature 2002, 415, 977-983. [CrossRef] [PubMed]

5. Group, M.; Ichimura, K.; Shinozaki, K.; Tena, G.; Sheen, J.; Henry, Y. Mitogen-activated protein kinase cascades in plants: A new nomenclature. Trends Plant Sci. 2002, 7, 301-308. [CrossRef]

6. Chen, Z.; Gibson, T.B.; Robinson, F.; Silvestro, L.; Pearson, G.; Xu, B. MAP kinases. Chem. Rev. 2001, 101, 2449-2476. [CrossRef] [PubMed]

7. Champion, A.; Picaud, A.; Henry, Y. Reassessing the MAP3K and MAP4K relationships. Trends Plant Sci. 2004, 9, 123-129. [CrossRef] [PubMed]

8. Jonak, C.; Ökrész, L.; Bögre, L.; Hirt, H. Complexity, cross talk and integration of plant MAP kinase signalling. Curr. Opin. Plant Biol. 2002, 5, 415-424. [CrossRef]

9. Mohanta, T.K.; Arora, P.K.; Mohanta, N.; Parida, P.; Bae, H. Identification of new members of the MAPK gene family in plants shows diverse conserved domains and novel activation loop variants. BMC Genom. 2015, 16, 58. [CrossRef] [PubMed]

10. Huang, X.; Luo, T.; Fu, X.; Fan, Q.; Liu, J. Cloning and molecular characterization of a mitogen-activated protein kinase gene from Poncirus trifoliata whose ectopic expression confers dehydration/drought tolerance in transgenic tobacco. J. Exp. Bot. 2011, 62, 5191-5206. [CrossRef] [PubMed]

11. Stulemeijer, I.J.; Stratmann, J.W.; Joosten, M.H. Tomato mitogen-activated protein kinases LeMPK1, LeMPK2, and LeMPK3 are activated during the Cf-4/Avr4-Induced hypersensitive response and have distinct phosphorylation specificities. Plant Physiol. 2007, 144, 1481-1494. [CrossRef] [PubMed]

12. Zaïdi, I.; Ebel, C.; Touzri, M.; Herzog, E.; Evrard, J.L.; Schmit, A. TMKP1 is a novel wheat stress responsive MAP Kinase phosphatase localized in the nucleus. Plant Mol. Biol. 2010, 73, 325-338. [CrossRef] [PubMed]

13. Khokhlatchev, A.V.; Canagarajah, B.; Wilsbacher, J.; Robinson, M.; Atkinson, M. Phosphorylation of the MAP kinase ERK2 promotes its homodimerization and nuclear translocation. Cell 1998, 93, 605-615. [CrossRef]

14. Nadarajah, K.; Sidek, H. The green MAPKs. Asian J. Plant Sci. 2010, 9, 1-10. [CrossRef]

15. Kumar, K.; Rao, K.P.; Biswas, D.K.; Sinha, A.K. Rice WNK1 is regulated by abiotic stress and involved in internal circadian rhythm. Plant Signal. Behav. 2011, 6, 316-320. [CrossRef] [PubMed]

16. Romeis, T. Protein kinases in the plant defence response. Curr. Opin. Plant Biol. 2001, 4, 407-414. [CrossRef] 
17. Yoo, S.D.; Cho, Y.H.; Tena, G.; Xiong, Y.; Sheen, J. Dual control of nuclear EIN3 by bifurcate MAPK cascades in C2H4 signalling. Nature 2008, 451, 789-795. [CrossRef] [PubMed]

18. Zhou, C.; Cai, Z.; Guo, Y.; Gan, S. An Arabidopsis mitogen-activated protein kinase cascade, MKK9-MPK6, plays a role in leaf senescence. Plant Physiol. 2009, 150, 167-177. [CrossRef] [PubMed]

19. Tena, G.; Asai, T.; Chiu, W.-L.; Sheen, J. Plant mitogen-activated protein kinase signaling cascades. Curr. Opin. Plant Biol. 2001, 4, 392-400. [CrossRef]

20. Xing, Y.; Cao, Q.Q.; Zhang, Q.; Shen, Y.Y.; Qin, L.; Zhang, J. MKK5 regulates high light-induced gene expression of $\mathrm{Cu} / \mathrm{Zn}$ superoxide dismutase 1 and 2 in Arabidopsis. Plant Cell. Physiol. 2013, 54, 1217-1227. [CrossRef] [PubMed]

21. Xing, Y.; Chen, W.; Jia, W.; Zhang, J. Mitogen-activated protein kinase kinase 5 (MKK5)-mediated signalling cascade regulates expression of iron superoxide dismutase gene in Arabidopsis under salinity stress. J. Exp. Bot. 2015, 66, 5971-5981. [CrossRef] [PubMed]

22. Teige, M.; Scheikl, E.; Eulgem, T.; Doczi, R.; Ichimura, K.; Shinozaki, K. The MKK2 pathway mediates cold and salt stress signaling in Arabidopsis. Mol. Cell 2004, 15, 141-152. [CrossRef] [PubMed]

23. Xing, Y.; Jia, W.; Zhang, J. AtMKK1 mediates ABA-induced CAT1 expression and $\mathrm{H}_{2} \mathrm{O}_{2}$ production via AtMPK6-coupled signaling in Arabidopsis. Plant J. 2008, 54, 440-451. [CrossRef] [PubMed]

24. Xing, Y.; Jia, W.; Zhang, J. AtMKK1 and AtMPK6 are involved in abscisic acid and sugar signaling in Arabidopsis seed germination. Plant Mol. Biol. 2009, 70, 725-736. [CrossRef] [PubMed]

25. Wang, J.; Ding, H.; Zhang, A.; Ma, F.; Cao, J.; Jiang, M. A novel Mitogen-activated protein kinase gene in maize (Zea mays), ZmMPK3, is involved in response to diverse environmental cues. J. Integr. Plant Biol. 2010, 52, 442-452. [CrossRef] [PubMed]

26. Zhang, A.; Zhang, J.; Ye, N.; Cao, J.; Tan, M.; Zhang, J. ZmMPK5 is required for the NADPH oxidase-mediated self-propagation of apoplastic $\mathrm{H}_{2} \mathrm{O}_{2}$ in brassinosteroid-induced antioxidant defence in leaves of maize. J. Exp. Bot. 2010, 61, 4399-4411. [CrossRef] [PubMed]

27. Pan, J.; Zhang, M.; Kong, X.; Xing, X.; Liu, Y.; Sun, L. ZmMPK17, a novel maize group D MAP kinase gene, is involved in multiple stress responses. Planta 2012, 235, 661-676. [CrossRef] [PubMed]

28. Lee, S.K.; Kim, B.G.; Kwon, T.R.; Jeong, M.J.; Park, S.R.; Lee, J.W. Overexpression of the mitogen-activated protein kinase gene OsMAPK33 enhances sensitivity to salt stress in rice (Oryza sativa L.). J. Biosci. 2011, 36, 139-151. [CrossRef] [PubMed]

29. Jeong, M.J.; Lee, S.K.; Kim, B.G.; Kwon, T.R.; Cho, W.S.; Park, Y.T. A rice (Oryza sativa L.) MAP kinase gene, OsMAPK44, is involved in response to abiotic stresses. Plant Cell Tissue Organ Cult. 2006, 85, 151-160. [CrossRef]

30. Rao, K.P.; Richa, T.; Kumar, K.; Raghuram, B.; Sinha, A.K. In silico analysis reveals 75 members of mitogen-activated protein kinase kinase kinase gene family in rice. DNA Res. 2010, 17, 139-153. [CrossRef] [PubMed]

31. Seo, S.; Katou, S.; Seto, H.; Gomi, K.; Ohashi, Y. The mitogen-activated protein kinases WIPK and SIPK regulate the levels of jasmonic and salicylic acids in wounded tobacco plants. Plant J. 2007, 49, 899-909. [CrossRef] [PubMed]

32. Kiegerl, S.; Cardinale, F.; Siligan, C.; Gross, A.; Baudouin, E.; Liwosz, A. SIMKK, a mitogen-activated protein kinase (MAPK) kinase, is a specific activator of the salt stress-induced MAPK, SIMK. Plant Cell 2000, 12, 2247-2258. [CrossRef] [PubMed]

33. Cardinale, F.; Meskiene, I.; Ouaked, F.; Hirt, H. Convergence and divergence of stress-induced mitogen-activated protein kinase signaling pathways at the level of two distinct mitogen-activated protein kinase kinases. Plant Cell 2002, 14, 703-711. [CrossRef] [PubMed]

34. Wang, J.; Pan, C.; Wang, Y.; Ye, L.; Wu, J.; Chen, L. Genome-wide identification of MAPK, MAPKK, and MAPKKK gene families and transcriptional profiling analysis during development and stress response in cucumber. BMC Genom. 2015, 16, 386. [CrossRef] [PubMed]

35. Galletti, R.; Ferrari, S.; DeLorenzo, G. Arabidopsis MPK3 and MPK6 play different roles in basal and oligogalacturonide-or flagellin-induced resistance against Botrytis cinerea. Plant Physiol. 2011, 157, 804-814. [CrossRef] [PubMed]

36. Frye, C.A.; Tang, D.; Innes, R.W. Negative regulation of defense responses in plants by a conserved MAPKK kinase. Proc. Natl. Acad. Sci. USA 2001, 98, 373-378. [CrossRef] [PubMed] 
37. Kumar, K.R.; Kirti, P.B. A mitogen-activated protein kinase, AhMPK6 from peanut localizes to the nucleus and also induces defense responses upon transient expression in tobacco. Plant Physiol. Biochem. 2010, 48, 481-486. [CrossRef] [PubMed]

38. Colcombet, J.; Hirt, H. Arabidopsis MAPKs: A complex signalling network involved in multiple biological processes. Biochem. J. 2008, 413, 217-226. [CrossRef] [PubMed]

39. Reyna, N.S.; Yang, Y. Molecular analysis of the rice MAP kinase gene family in relation to Magnaporthe grisea infection. Mol. Plant Microbe. Interact. 2006, 19, 530-540. [CrossRef] [PubMed]

40. Liu, Q.; Xue, Q. Computational identification and phylogenetic analysis of the MAPK gene family in Oryza sativa. Plant Physiol. Biochem. 2007, 45, 6-14. [CrossRef] [PubMed]

41. Wankhede, D.P.; Misra, M.; Singh, P.; Sinha, A.K. Rice mitogen activated protein kinase kinase and mitogen activated protein kinase interaction network revealed by in-silico docking and yeast two-hybrid approaches. PLoS ONE 2013, 8, e65011. [CrossRef] [PubMed]

42. Birsen, C.; Ozan, K. Mitogen-activated protein kinase cascades in Vitis vinifera. Front. Plant Sci. 2015, 6, 556.

43. Shulaev, V.; Sargent, D.J.; Crowhurst, R.N.; Mockler, T.C.; Folkerts, O.; Delcher, A.L. The genome of woodland strawberry (Fragaria vesca). Nat. Genet. 2011, 43, 109-116. [CrossRef] [PubMed]

44. Major, G.; Daigle, C.; Stafford-Richard, T.; Tebbji, F.; Lafleur, E.; Caron, S. Characterization of ScMAP4K1, a MAP kinase kinase kinase kinase involved in ovule, seed and fruit development in Solanum chacoense Bitt. Curr. Top. Plant. Biol. 2009, 10, 27-46.

45. Bögre, L.; Calderini, O.; Binarova, P.; Mattauch, M.; Till, S.; Kiegerl, S. A MAP kinase is activated late in plant mitosis and becomes localized to the plane of cell division. Plant Cell 1999, 11, 101-113. [CrossRef] [PubMed]

46. Hwa, C.M.; Yang, X.C. The AtMKK3 pathway mediates ABA and salt signaling in Arabidopsis. Acta. Physiol. Plantarum. 2008, 30, 277-286. [CrossRef]

47. Mizoguchi, T.; Irie, K.; Hirayama, T.; Hayashida, N.; Yamaguchi-Shinozaki, K.; Matsumoto, K. A gene encoding a mitogen-activated protein kinase kinase kinase is induced simultaneously with genes for a mitogen-activated protein kinase and an 66 ribosomal protein kinase by touch, cold, and water stress in Arabidopsis thaliana. Proc. Natl. Acad. Sci. USA 1996, 93, 765-769. [CrossRef] [PubMed]

48. Berberich, T.; Sano, H.; Kusano, T. Involvement of a MAP kinase, ZmMPK5, in senescence and recovery from low-temperature stress in maize. Mol. Gen. Genet. 1999, 262, 534-542. [CrossRef] [PubMed]

49. Doczi, R.; Brader, G.; Pettko-Szandtner, A.; Rajh, I.; Djamei, A.; Pitzschke, A. The Arabidopsis mitogen-activated protein kinase kinase MKK3 is upstream of group $\mathrm{C}$ mitogen-activated protein kinases and participates in pathogen signaling. Plant Cell 2007, 19, 3266-3279. [CrossRef] [PubMed]

50. Mockaitis, K.; Howell, S.H. Auxin induces mitogenic activated protein kinase (MAPK) activation in roots of Arabidopsis seedlings. Plant J. 2000, 24, 785-796. [CrossRef] [PubMed]

51. Liu, Y. Roles of mitogen-activated protein kinase cascades in ABA signaling. Plant Cell Rep. 2012, 31, 1-12. [CrossRef] [PubMed]

52. Xu, J.; Li, Y.; Wang, Y.; Liu, H.X.; Lei, L.; Yang, H.L. Activation of MAPK kinase 9 induces ethylene and camalexin biosynthesis and enhances sensitivity to salt stress in Arabidopsis. J. Biol. Chem. 2008, 283, 26996-27006. [CrossRef] [PubMed]

53. Zhang, S.; Klessig, D.F. MAPK cascades in plant defense signaling. Trends Plant Sci. 2001, 6, 520-527. [CrossRef]

54. Yuasa, T.; Ichimura, K.; Mizoguchi, T.; Shinozaki, K. Oxidative stress activates ATMPK6, an Arabidopsis homologue of MAP kinase. Plant Cell Physiol. 2001, 42, 1012-1016. [CrossRef] [PubMed]

55. Selim, S.; Sanssené, J.; Rossard, S.; Courtois, J. Systemic induction of the defensin and phytoalexin pisatin pathways in pea (Pisum sativum) against Aphanomyces euteiches by acetylated and nonacetylated oligogalacturonides. Molecules 2017, 22, 1017. [CrossRef] [PubMed]

56. Larkin, M.A.; Blackshields, G.; Brown, N.P.; Chenna, R.; McGettigan, P.A.; McWilliam, H. Clustal W and Clustal X version 2.0. Bioinformatics 2007, 23, 2947-2948. [CrossRef] [PubMed]

57. Tamura, K.; Peterson, D.; Peterson, N.; Stecher, G.; Nei, M.; Kumar, S. MEGA5: Molecular evolutionary genetics analysis using maximum likelihood, evolutionary distance, and maximum parsimony methods. Mol. Biol. Evol. 2011, 28, 2731-2739. [CrossRef] [PubMed]

(C) 2017 by the authors. Licensee MDPI, Basel, Switzerland. This article is an open access article distributed under the terms and conditions of the Creative Commons Attribution (CC BY) license (http://creativecommons.org/licenses/by/4.0/). 